\title{
Brasolia, a new genus highlighted from Sobralia (Orchidaceae)
}

\author{
Przemyslaw Baranow $^{1}$ (D) Magdalena Dudek $^{1} \cdot$ Dariusz L. Szlachetko $^{1}$
}

Received: 10 February 2016/Accepted: 27 March 2017/Published online: 21 April 2017

(C) The Author(s) 2017. This article is an open access publication

\begin{abstract}
A phylogenetic study of Sobralia (Orchidaceae) confirmed the polyphyletic character of the genus. Sobralia also appears to be highly heteromorphic in the morphology, especially considering the position and architecture of inflorescence, lip form and kind of its outgrowths, length and form of stelidia of column. The infrageneric relationship of Sobralia species was revealed by analyses of three DNA markers (nuclear ITS, $x d h$ and plastid matK). The nominal section of the genus appears to be more related with Elleanthus and other genera of Sobralieae than with the remaining species of Sobralia. Sobralia section Sobralia differs from other representatives of the genus by the position and architecture of inflorescence, smaller floral bracts and the morphology of the flowers. We propose a generic rank to the group despite its paraphyletic nature. Nomenclatural consequences of this proposal are briefly discussed. Appropriate transfers to the newly erected genus Brasolia are proposed. A new species, Brasolia floribunda, previously detected by Reichenbach, but never formally described, is validated. Lectotypes for five species and a neotype for the other one are proposed.
\end{abstract}

Keywords Classification $\cdot$ New genus · Orchidaceae · Phylogeny $\cdot$ Sobralia

Handling editor: Mark Mort.

Electronic supplementary material The online version of this article (doi:10.1007/s00606-017-1413-z) contains supplementary material, which is available to authorized users.

Przemyslaw Baranow

przemyslaw.baranow@biol.ug.edu.pl

1 Department of Plant Taxonomy and Nature Conservation, Faculty of BiologyThe University of Gdansk, Gdansk, Poland

\section{Introduction}

The orchid genus Sobralia Ruiz \& Pav. is widely distributed in the New World tropics and subtropics. In some areas, particularly in the mountains, Sobralia species are found in large quantities, occasionally forming bamboolike thickets. Despite local abundance, Sobralia seems to be one of the lesser known orchid genera. This is partially caused by difficulty in the preservation of the flowers during desiccation of herbarium specimens and later examination of the dried flowers themselves. Notably, analyses of dried flowers are a challenge for every taxonomist working with this genus, the typically large flowers with usually thin, very delicate segments, and especially the labellum often covered by various kinds of outgrowths, and require a lot of patience and experience. Taxonomic work is also complicated by insufficient material useful for morphological study. Herbarium specimens often do not have flowers that could be adequate for proper examination, or in the case of large species they include only part of the plant.

Since the formal description of the genus (Ruiz and Pavon 1794), the number of species has increased to about 200. They are distributed from southern Mexico to Brazil and Bolivia. Species of Sobralia grow in various habitats, from humid and shaded tropical forests to sunny, dry, open savannas or roadsides, from sea level up to over $3000 \mathrm{~m}$, where they can occur as terrestrial, lithophytic or epiphytic plants.

Sobralia, together with Elleanthus C.Presl, Sertifera Lindl. \& Rchb.f. and Epilyna Schltr., represents the tribe Sobralieae described by Pfitzer in 1887, based on a grasslike habit with plicate leaves and usually terminal inflorescences. The taxon was temporarily treated as a subtribe, Sobraliinae Schltr., and placed in the tribe Arethuseae 
Lindl. (Dressler 1981) or Epidendreae (Dressler 1993). Szlachetko (1995) divided the group and placed Elleanthus, Sertifera and Epilyna into the tribe Elleantheae Szlach. of the Epidendroideae Lindl., leaving Sobralia in Sobraliinae within Arethuseae in Vanilloideae (Lindl.) Szlach. This opinion was based on the differences in the gynostemium structure, particularly pollinia.

Considering the results of molecular studies, the aforementioned genera form a monophyletic clade within Epidendroideae (Pridgeon et al. 1999, 2005). Pridgeon et al. (2005) characterized Sobralieae as plants with fleshy roots covered with velamen and reed-like, not pseudobulbous stems, with distichous, plicate or rarely conduplicate, articulated leaves, racemose or condensed, terminal or axillary inflorescence with small flowers. The exception is Sobralia, which usually has large, ephemeral flowers. There are four or eight flattened, obovoid to globose, soft pollinia in this tribe. The subfamily Epidendroideae sensu Pridgeon et al. is characterized by coherent, definite pollinia. Thus, there is a discrepancy with the state observed in Sobralia. Pollinia of the subfamily Vanilloideae sensu Pridgeon are described as "mealy, paste-like, not coherent," so similar to those found in Sobralia.

Sobralia is a morphologically diverse group of species, especially with regard to the position and structure of inflorescence and structure of floral bracts and flowers. The differences permit distinguishing some groups within the genus that were the basis for description of the infrageneric taxa (Lindley 1854; Reichenbach 1873; Brieger 1983). The present classification of Sobralia is based on Briegers' division of the genus into five sections (Table 1). The groups were studied by Dressler (2002) who accepted the
Briegers' classification, but at the same time emphasized that there are species of Sobralia that cannot be classified within any of the groups because of their morphological distinctness. However, the most problematic aspect of $\mathrm{So}$ bralia taxonomy seems to be its actual nominal section. Neubig et al. (2011) and Dressler et al. (2011) noted that most of its species form a paraphyletic grade, which is more closely related to Elleanthus, Epilyna and Sertifera than to the other Sobralia sections. Additionally, members of section Sobralia are morphologically distinct from other species of the genus. The authors concluded that the splitting of the genus is imminent. The problem is that the nominal section would have to be left as Sobralia with $S$. dichotoma as the generic type and all other species would have to be transferred to Cyathoglottis Poepp. \& Endl.the oldest available synonym of Sobralia. Taking into account the number of species that would have to be transferred, and the fact that many of them are common in cultivation as ornamental plants, such reorganization of the group could cause confusion. That is why Dressler et al. (2011) proposed to conserve Sobralia with S. biflora Ruiz \& Pav. as the conserved type. Unfortunately, no further nomenclatural changes within the genus have been made since the publication of the proposal by Dressler et al. (2011).

Our study on the taxonomy of Sobralia allowed us to confirm the distinctness of its nominal section noticed by the aforementioned authors. Morphological analyses and the reconstruction of the genus-level phylogeny based on the molecular data clearly show that the section deserves status as a separate genus. The major goal of this paper is to present these results and to propose the taxonomic changes

Table 1 Comparison of infrageneric classifications of Sobralia Ruiz \& Pav.

\begin{tabular}{|c|c|c|c|}
\hline Lindley (1854) & $\begin{array}{l}\text { Reichenbach } \\
\text { (1873) }\end{array}$ & Brieger (1983) & Dressler (2002) \\
\hline $\begin{array}{l}\text { A (flowers in a naked } \\
\text { flexuose raceme. Bracts } \\
\text { very short) }\end{array}$ & $\begin{array}{l}\text { Brasolia } \text { Rchb.f. } \\
\text { (inflorescence } \\
\text { lateral) }\end{array}$ & $\begin{array}{l}\text { Sobralia (inflorescence } \\
\text { lateral, } \pm \text { elongated) }\end{array}$ & $\begin{array}{l}\text { Sobralia (floral bracts shorter than pedicel and } \\
\text { ovary) }\end{array}$ \\
\hline $\begin{array}{l}\text { B (flowers in a flexuose } \\
\text { raceme, with distant } \\
\text { cymbiform foliaceous } \\
\text { bracts) }\end{array}$ & $\begin{array}{l}\text { Eusobralia } \\
\text { Rchb. f. } \\
\text { (inflorescence } \\
\text { terminal) }\end{array}$ & $\begin{array}{l}\text { Racemosae Brieger (inflorescence } \\
\text { terminal, racemosae, with distinct } \\
\text { internodes and large floral bracts) }\end{array}$ & $\begin{array}{l}\text { Racemosae Brieger (floral bracts longer than } \\
\text { pedicel and ovary) }\end{array}$ \\
\hline \multirow[t]{3}{*}{$\begin{array}{l}\mathrm{C} \text { (flowers in a cone-like } \\
\text { head or naked. }\end{array}$} & $\begin{array}{l}\text { Eusobralia } \\
\text { Rchb. f. } \\
\text { (inflorescence } \\
\text { terminal) }\end{array}$ & $\begin{array}{l}\text { Abbreviatae Brieger (inflorescence } \\
\text { terminal, sessile, condensed, without } \\
\text { visible internodes, bracts imbricating. }\end{array}$ & $\begin{array}{l}\text { Abbreviatae Brieger (inflorescence condensed, with } \\
\text { very short internodes, floral bracts forming } \\
3-6 \mathrm{~cm} \text { long cone-like structure not enlarging } \\
\text { after flowering starts) }\end{array}$ \\
\hline & & $\begin{array}{l}\text { Intermediae Brieger (inflorescence on } \\
\text { long and distinct peduncle, rachis } \\
\text { condensed, without visible internodes) }\end{array}$ & $\begin{array}{l}\text { Intermediae Brieger (inflorescence condensed, with } \\
\text { very short internodes, bract clusters less than } 3 \mathrm{~cm} \\
\text { long) }\end{array}$ \\
\hline & & $\begin{array}{l}\text { Globosae Brieger (inflorescence } \\
\text { shortened, covered with floral bracts) }\end{array}$ & $\begin{array}{l}\text { Globosae Brieger (inflorescence condensed, bracts } \\
\text { forming a cone-like structure growing in length) }\end{array}$ \\
\hline
\end{tabular}


aimed to clarify Sobralia taxonomy. Taking another step of the process initiated by Dressler et al. (2011), we transform the species of the nominal section of Sobralia into a new genus-Brasolia.

\section{Materials and methods}

\section{Morphological study}

The data we present here were collected as the result of the examination of 1909 herbarium specimens (1420 collections) deposited at AMES, B, BM, COL, COAH, K, L, MA, MO, NY, P, U, UGDA, US and $\mathrm{W}$, the spirit collections of COL and UGDA (herbaria acronyms according to Thiers (2017)) and living specimens cultivated in greenhouses of the University of Gdansk (Faculty of Biology).

The morphological characters examined are the following: stem height, the presence of keikis and branches, surface cover; leaf number, size, shape, surface area, arrangement along the stem; and inflorescence position on the plant, form, size, floral bract size and shape, number of open flowers at any given time. Flowers (if available) were analyzed after rehydration (except for those preserved in liquid). Floral segments were drawn taking into account their form, size, type of margins and apex shapes. The labellum surfaces were observed under a stereomicroscope to analyze potential calli, hairs or thickenings of nerves. We also observed and illustrated the column with special attention to size and shape, and the form of the column wings, which are often a diagnostic feature.

\section{Morphological approaches}

We selected the most distinctive characters that are used for species delimitation and converted them into binary characters for morphological analyses (Online Resource 1). The data matrix includes the taxonomically valuable features allowing for the determination of analyzed species, which were chosen basing on authors' experience and publications analyzing the infrageneric classification of the group (Brieger 1983; Dressler 2002; Lindley 1854). We compared representatives of each genus of the subtribe (including Elleanthus C.Presl sensu Dudek and Szlachetko (2010), Adeneleutherophora Barb.Rodr., Epilyna Schltr. and Evelyna Poepp. \& Endl.) with a selection of Sobralia species that had been included in molecular studies (see "Molecular Study" below) and that also represent the full spectrum of morphologies in the genus. The total number of analyzed taxa is 70, including 63 Sobralia species and 7 species of other Sobralieae genera. The final data matrix comprises 42 characters.
Hierarchical phenograms were obtained with the PAST 3.14 program (Hammer et al. 2001) UPGMA and neighbor joining methods (Saitou and Nei 1987). In both cases, the Euclidean distance method was used to create the cladograms.

\section{Molecular study}

Most of the samples used for molecular study were obtained from plants purchased from Colombian, Ecuadorean and Peruvian nurseries (Orquivalle, Ecuagenera, Peruflora). However, some samples (leaf fragments) were received from private collections and from the Botanical Gardens of Vienna and Heidelberg (Online Resource 2). Seven sequences for ITS were taken from Neubig (2011). In total, DNA sequences for ITS/matK/Xdh were obtained from 73/56/50 taxa of Sobralieae. The outgroup includes three species of Tropidieae (Tropidia graminea Blume, T. polystachya (Sw.) Ames and Neottieae (Neottia nidusavis (L.) Rich.). Sequences of outgroup taxa and for five representatives of Elleanthus sensu lato were downloaded from GenBank (Online Resource 2). Outgroup taxa were selected with reference to previous publications analyzing the phylogenetic placement of Sobralia and related genera (Neubig 2011).

\section{Molecular markers}

Molecular analyses were based on three markers: two nuclear (ITS, Xdh) and one plastid (matK) genome region. The ITS region consisted of the ITS1-5.8S-ITS2 genes. Amplifications of the ITS region were performed using the primers $101 \mathrm{~F}$ (5'ACGAATTCATGGTCCGGTGAAGT GTTCG3') and 102R (5'TAGAATTCCCCGGTTCGCT CGCCGTTAC3') (Douzery et al. 1999). We amplified part of the ITS region (ITS1-5.8S-ITS2).

$X d h$ is a low-copy, highly conserved nuclear coding gene, which is used as an effective marker for phylogenetic analyses (Zhang et al. 2012). For amplification, we used the primers X551F (5'GAAGAGCAGATTGAAGA(AT) (AT)GCC $\left.3^{\prime}\right)$ and X1591R (5'AA(CT)TGGAGCAACTCC ACCA3') (Górniak et al. 2011).

For the matK gene, we amplified a fragment of approximately $1400 \mathrm{bp}$ using the primers $19 \mathrm{~F}$ ( $5^{\prime}$ CGTTC TGACCATATTGCACTATG3') from Molvary et al. (2000) and 1326R (5'TCTAGCACACGAAAGTCGAA GT3') from Cuénoud et al. (2002).

\section{DNA extraction, amplification and sequencing}

We preserved our fresh leaf samples in silica gel (Chase and Hills 1991) and extracted DNA using a Genomic Mini AX Plant Kit (A\&A Biotechnology, Poland) following 
manufacturer's protocol. A pellet of DNA was resuspended in $50 \mu \mathrm{l}$ of dd $\mathrm{H} 2 \mathrm{O}$.

We used Eppendorf and Biometra thermocyclers for amplifications and sequencing. PCRs for all the markers were performed in a total volume of $25 \mu \mathrm{l}$, containing $1 \mu \mathrm{l}$ temple DNA ( 10-100 ng), $0.5 \mu \mathrm{l}$ of $10 \mu \mathrm{M}$ of each primer, $1.0 \mu \mathrm{l}$ dimethyl sulfoxide (DMSO), $12.5 \mu \mathrm{l}$ HotStart PCR Mix-StartWarm 2× PCR Master Mix (A\&A Biotechnology, Poland) and water. A touchdown protocol was used for PCR amplification for nrITS (ITS1 + 5.8$\mathrm{S}+$ ITS2): $94{ }^{\circ} \mathrm{C}, 4 \mathrm{~min} ; 30 \mathrm{X}\left(94{ }^{\circ} \mathrm{C}, 45 \mathrm{~s} ; 52{ }^{\circ} \mathrm{C}, 45 \mathrm{~s}\right.$; $\left.72{ }^{\circ} \mathrm{C}, 1 \mathrm{~min}\right) ; 72{ }^{\circ} \mathrm{C}, 7 \mathrm{~min}$. Amplification parameters for the $X d h$ gene were: The initial denaturation step $\left(95^{\circ} \mathrm{C}\right.$, $5 \mathrm{~min}$ ) was followed by seven cycles of $94^{\circ} \mathrm{C}, 45 \mathrm{~s} ; 59^{\circ} \mathrm{C}$, $45 \mathrm{~s}$ (reducing $1{ }^{\circ} \mathrm{C}$ per cycle); $72{ }^{\circ} \mathrm{C}, 90 \mathrm{~s}$. The next $30 \mathrm{X}$ $\left(94{ }^{\circ} \mathrm{C}, 45 \mathrm{~s} ; 52{ }^{\circ} \mathrm{C}, 45 \mathrm{~s} ; 72{ }^{\circ} \mathrm{C}, 90 \mathrm{~s}\right) ; 72{ }^{\circ} \mathrm{C}, 10 \mathrm{~min}$. For the matK fragment, we set the following parameters: $95^{\circ} \mathrm{C}, 3 \mathrm{~min} ; 33 \mathrm{X}\left(94{ }^{\circ} \mathrm{C}, 45 \mathrm{~s} ; 52{ }^{\circ} \mathrm{C}, 45 \mathrm{~s}, 72^{\circ} \mathrm{C}, 2 \mathrm{~min}\right.$ $30 \mathrm{~s}) ; 72^{\circ} \mathrm{C}, 7 \mathrm{~min}$. Wizaed SvGel and a PCR Clean Up System (Promega, US) were used to clean PCR products following the manufacturer's protocol, eluted with $30 \mu \mathrm{l}$ of Nuclease-Free Water. Purified PCR products were cyclesequenced using a Big Dye Terminator v 3.1 Cycle Sequencing Kit (Applied Biosystems, Inc., ABI, Warrington, Cheshire, UK). Cycle sequencing parameters were: $95{ }^{\circ} \mathrm{C}, 2 \mathrm{~min} 40 \mathrm{~s} ; 25 \mathrm{X}\left(95^{\circ} \mathrm{C}, 10 \mathrm{~s} ; 50{ }^{\circ} \mathrm{C}, 10 \mathrm{~s} ; 60^{\circ} \mathrm{C}\right.$, $4 \mathrm{~min}$ ). The total volume of sequencing reaction was $10 \mu \mathrm{l}$ containing $1.3 \mu \mathrm{l}$ of $5 \mathrm{X}$ sequencing buffer, $1 \mu \mathrm{l}$ of Big Dye terminator, $0.4 \mu \mathrm{l}$ of $10 \mu \mathrm{M}$ primer (1.6/3.2 pmol), $0.5 \mu \mathrm{l}$ dimethyl sulfoxide (DMSO), $1 \mu \mathrm{l}$ of amplified product (30-90 ng/ $\mu \mathrm{l}$ ) and water. The sequencing reaction products were then purified and sequenced on an ABI 3720 automated capillary DNA sequencer in Genomed S.A. company (Warsaw, Poland). DNA sequence chromatograms were examined/edited in FintchTV, and forward and reverse sequence reads were assembled using AutoAssembler (Applied Biosystems, Inc). All sequences were deposited in GenBank (Online Resource 2).

\section{Data analyses}

The DNA sequences of both nuclear markers (ITS, $X d h$ ) and part of the matK gene were manually aligned with Seaview (Galtier et al. 1996). Data matrices are available as supporting material (Online Resources 3-5). The data were analyzed with two methods: maximum parsimony (MP) and Bayesian inference (BI). Maximum parsimony analyses were undertaken separately on three matrices using heuristic searches in PAUP*4.0b10 (Swofford 2000) with tree-bisection-reconnection (TBR) branch swapping and the MULTREES option in effect, simple addition and ACCTRAN optimization. All characters were unordered and equally weighted (Fitch
Fig. 1 Results of phenetic analysis. Neighbor joining dendrogram, Euclidean distance

1971). Missing data were coded as “?”, and gaps were coded as “.". All parsimonious trees $(10,000)$ were used to determine strict consensus tree, which are available as supporting material (2-5). The internal support of clades was evaluated by the bootstrap (Felsenstein 1985) using 1000 bootstrap replicates. For bootstrap support levels, we considered bootstrap percentages (BP) of 50-70\% as weak, $71-85 \%$ as moderate and $>85 \%$ as strong (Kores et al. 2001).

We performed the Bayesian analyses using Markov chain Monte Carlo (MCMC) in MrBayes 3.1.2 (Ronquist and Huelsenbeck 2003). Molecular substitution model for each examined region was calculated with MrModeltest 2.2 (Nylander 2004). It was selected as the best fitting by both hLRTs (hierarchical likelihood ratio test) and AIC (Akaike information criterion). In both cases was established the same model. For the ITS and matK matrices, GTR $+\mathrm{G}+\mathrm{I}$ and for the $X d h$ dataset, the HKY $+\mathrm{G}$ model was selected. Each analysis consisted of two simultaneous runs of four chains for 10,000,000 generations, sampling one tree for each 100, until the average standard deviation of split ranges was smaller than 0.01 . A maximum clade credibility tree was constructed using TreeAnnotator v1. 8.1 (Drummond et al. 2012), with a burn-in of $25 \%$. The support of the clades was evaluated by the posterior probability (PP). The PP values generally are much higher than bootstrap percentages, and therefore, they are not equivalent to bootstrap percentages. For the PP values, we considered $\mathrm{PP}>95 \%$ as strongly supported, PP 90-95\% as moderately supported and $\mathrm{PP}<90 \%$ as weakly supported (Erixon et al. 2003).

\section{Results}

\section{Morphological analyses}

The results of morphological analyses illustrate the high level of variability of studied features. The tree based on the neighbor joining method (Fig. 1) shows Sobralieae divided into two groups: I and II. The first one embraces most sections Sobralia, and the second-Sobralia sect. Racemosae along with other representatives of the Sobralieae. Group I is then subdivided into two clusters: A and $\mathrm{B}$.

Species of cluster A are characterized by terminal, abbreviated inflorescences. This cluster has two subclusters (Fig. 1; A a, b). The subcluster "a" can be characterized by having an entire or retuse labellum apex, and subcluster "b" is distinguished by its deeply bilobed labellum. 




sect. Abbreviatae

sect. Globosae

sect. Intermediae



sect. Abbreviatae

complex S. undatocarinata

sect. Sobralia

other Sobralieae

sect. Racemosae 
Subcluster "a" embraces two assemblages. The first (Fig. 1; I A a 1) includes species of Abbreviatae Brieger species: S. andreae Dressler, S. citrea Dressler, S. warszewiczii Rchb.f., S. cobanensis Archila, S. klotzscheana Rchb.f., S. recta Dressler, S. atropubescens Ames \& C.Schweinf., S. melanothrix Løjtnant, S. tricolor Dressler, S. decora Bateman, S. yuaperyensis Barb.Rodr., S. violacea Linden ex Lindl. and S. valida Rolfe (all section Abbreviatae). The second (Fig. 1; I A a 2) is formed by species of section Globosae Brieger-S. lancea Garay, S. quinata Dressler and S. candida (Poepp. \& Endl.) Rchb.f.; section Intermediae Brieger $-S$. crocea (Poepp. \& Endl.) Rchb.f., $S$. mucronata Ames \& C.Schweinf. and $S$. alleni L.O.Williams, and representatives of the section Abbreviatae (S. fimbriata Poepp. \& Endl., S. withneri D.E.Benn. \& Christenson and $S$. wilsoniana Rolfe, intermixed with $S$. fragrans Lindl. (section Intermediae).

Subcluster "b" is composed of species with deeply bilobed labellum apex representing Abbreviatae section plus S. macrophylla Rchb.f. and S. madisonii Dodson (Fig. 1; A b 3). The two latter species are treated as unclassified by Dressler et al. (2011), because their inflorescences are hidden between funnel-shaped bases of apical leaves. The subcluster also includes $S$. undatocarinata C.Schweinf., S. sanfelicis Dressler and S. maduroi Dressler, but the three species form a sister group in relation with the above-mentioned (Fig. 1; A b 4). Apparently, their narrow leaves and very unusual labellum, which is constricted in the middle, affected their position on the phenogram.

The remaining part of the group I (Fig. 1; I) is divided into two well-separated branches composed of Sobralia section Sobralia (Fig. 1; I B), combined with an unclassified (Dressler 2002) S. luteola Rolfe (Fig. 1; B 5). The close relation is probably caused by the similar structure of the inflorescence with distinct internodes and with flowers and floral buds at various stage of development. However, taking into account the position of the inflorescence and morphology of the flowers, S. luteola cannot be included in Sobralia section.

The second group of species (Fig. 1; II) consists of Elleanthus, Evelyna, Adeneleuterophora, Epilyna and Sertifera (Fig. 1; II C), which are sister to Sobralia section Racemosae (Fig. 1; II D). We have not been able to retrieve any mutual morphological characters for this group.

The UPGMA tree (Fig. 2) presents a similar pattern within the tribe. Species of Sobralia form a group (Fig. 2; I) distinctly separated from other members of the tribe (Fig. 2; II). Sobralia is divided into two main groups: One is composed of the nominal section (Fig. 2; I B) constituting a sister group to another, large clade of remaining Sobralia species (Fig. 2; I A). This emphasizes the distinctness of the morphology of nominal section. The core
Fig. 2 Results of phenetic analysis. UPGMA dendrogram, Euclidean distance

Sobralia is divided into two clusters: One (Fig. 2; I A a) is composed of species with floral bracts shorter than the ovary (S. alleni, S. crocea, S. mucronata, S. wilsoniana, S. fimbriata, S. whitneri, S. fragrans, S. lancea, S. quinata and S. candida), while the other (Fig. 2; I A b) includes species with floral bracts longer than the ovary. The last one is divided again into subclusters: Species representing Racemosae along with S. luteola ("b" Fig. 2; I A b 2) form a sister group to the subcluster composed of the species without visible internodes of the inflorescences ("b" Fig. 2; I A b 1). In the latter subcluster, S. maduroi, $S$. sanfelicis and $S$. undatocarinata are grouped together and form a sister group for the remaining species.

Adeneleuterophora, Elleanthus, Epilyna, Evelyna and Sertifera are clustered together and form an assemblage (Fig. 2II) which is a sister group in relation with a large clade composed of all the studied Sobralia species (Fig. 2I).

\section{Molecular analyses}

The results of the parsimony and Bayesian analyses gave similar results. Thus, we present and discuss the maximum clade credibility trees only. The strict consensus trees are attached as the Online Resources 6-8. The clades that have low support for bootstrap values in the trees of parsimony analyses also have low posterior probability values in trees which were resulted of Bayesian analyses.

Both molecular analyses based on ITS (MP, BI) showed Sobralia to be a paraphyletic taxon. It is split into two main groups: one composed of species representing most sections (Abbreviatae, Globosae, Intermediae and Racemosae) (Fig. 3; I) and the other one consisting of nominal section intermixed with species of Elleanthus, Epilyna and Sertifera (Fig. 3; II). Both clades are strongly supported $(\mathrm{PP}=100)$. Surprisingly, Sobralia ciliata (C.Presl) C.Schweinf. \& Foldats - one of the members of the nominal section forms a basal branch for the main clade of Sobralieae. This situation is difficult to explain because the species has small floral bracts and lateral, often branched inflorescences, which are the morphological hallmarks of section Sobralia. The other species with an unexpected position is S. liliastrum Lindl., which, taking into account its morphology, should be classified in Racemosae section. Species of the group ( $S$. gloriosa Rchb.f. and S. rosea Poepp. \& Endl., S. pulcherrima Garay) form a well-separated, highly supported (PP $=100$ ) group (Fig. 3; I A). While $S$. liliastrum was supposed to be a part of the clade, it forms a sister taxon to the main clade of Sobralia, including Racemosae section. 


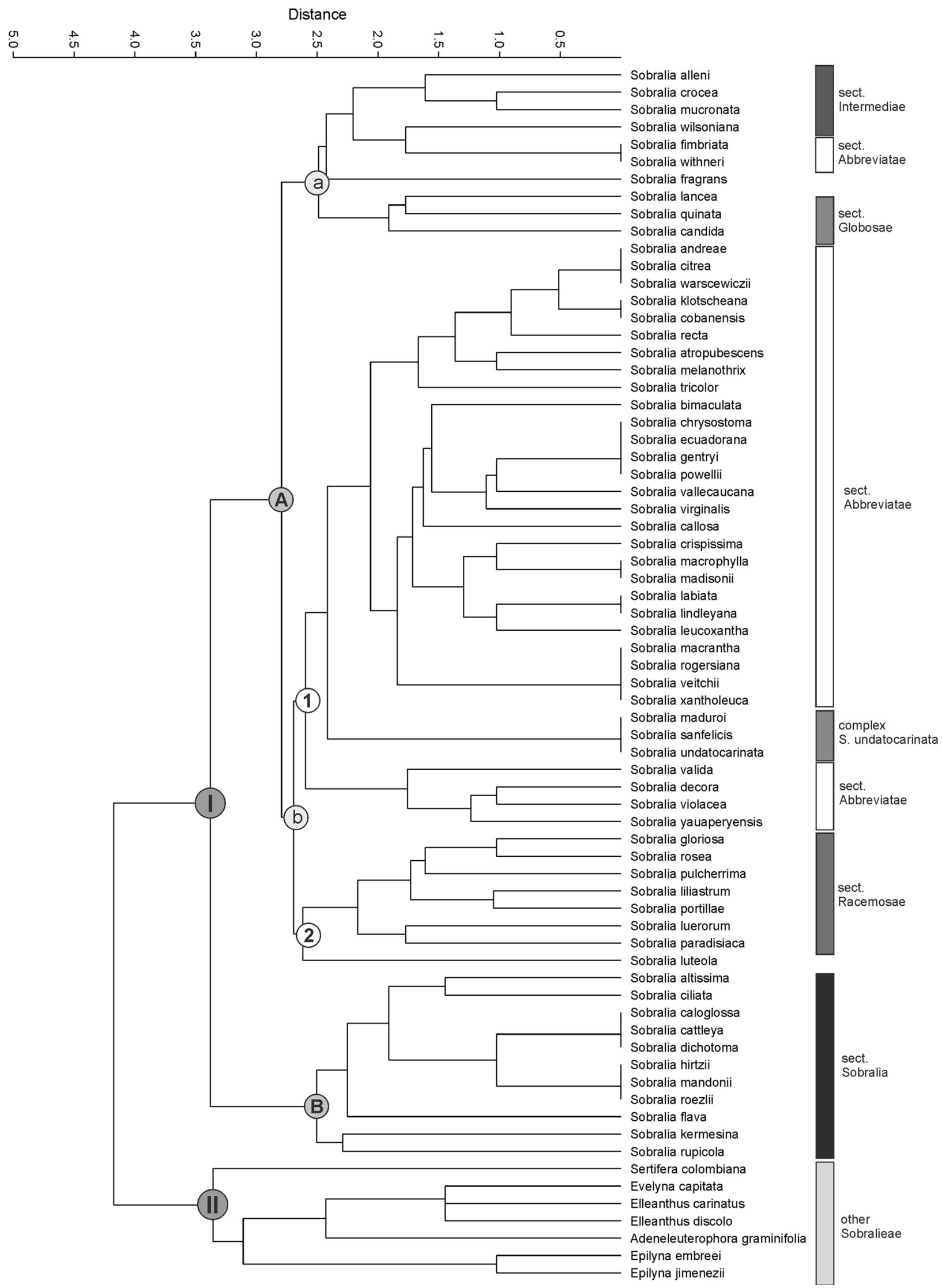




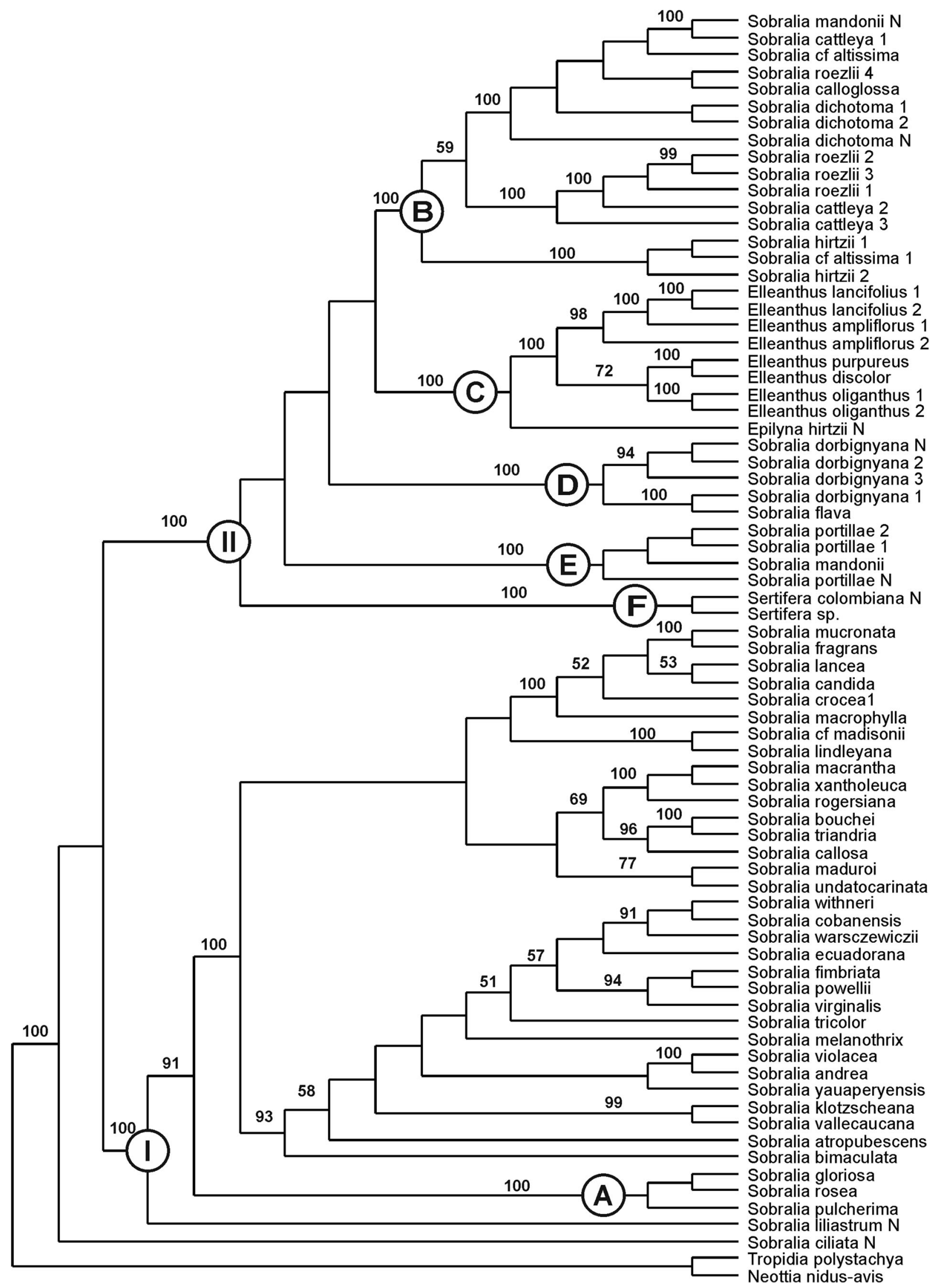


4Fig. 3 Bayesian 50\% majority-rule tree for Sobralieae from ITS15.8S-ITS2 sequences. The branches length is shown above. Values below branches represent bootstrap support $(\geq 50 \%)$ from 1000 replicates and posteriori probabilities $(\geq 50 \%)(\mathrm{bp} / \mathrm{pp}) ; N$ denotes sequences obtained from Neubig (2011)

The remaining part of the tree (Fig. 3; II) results in the conclusion that the current section Sobralia is paraphyletic, and suggests that the group should be combined with Ellenathus and the other genera of the tribe. The fragment of the phylogram consists of five polyatomic clades (Fig. 3; II B-F). Most of the species of the nominal section (S. altissima D.E.Benn. \& Christenson, S. caloglossa Schltr., cattleya Rchb.f., S. dichotoma Ruiz \& Pav., S. hirtzii Dodson, S. mandonii Rchb.f. and S. roezlii Rchb.f.) form one of them (Fig. 3; II B). Samples representing Sobralia dorbignyana Rchb.f. and S. flava Baranow \& Szlach. form another clade (Fig. 3; II D), and the third is a clade formed by $S$. portillae Christenson (Fig. 3; II E). Two remaining clades are composed of Ellenathus sensu lato (Fig. 3; II C) and well-separated Sertifera Lindl. \& Rchb.f. (Fig. 3; II F).

The cladogram based on the $x d h$ marker (Fig. 4) presents somewhat different topology, although it confirms the abovementioned distinctness of the section Sobralia. Samples of section Racemosae (S. gloriosa and S. rosea) form an earlybranching clade (Fig. 4; II) that is sister to a clade composed of other species of Sobralieae (Fig. 4; I). The tribe is divided into two clades (Fig. 4; I A and B), and both of them are also divided into two weakly supported subclades. One of these four groups (Fig. 4; I B a) includes cluster of sections Intermediae (S. crocea (Poepp. \& Endl.) Rchb.f., S. mucronata Ames \& C.Schweinf.), Abbreviatae (S. bimaculata Garay), Globosae (S. candida (Poepp. \& Endl.) Rchb.f., S. lancea Garay) and S. macrophylla Rchb.f. which is not assigned to any section by Dressler (2002). The subclade forms a sister group for an assemblage (Fig. 4; I B b) composed of $S$. bouchei Ames \& C.Schweinf., S. callosa L.O.Williams, and $S$. lindleyana Rchb.f. Within clade "I A" (Fig. 4), there are two clades recovered with weak support. One clade (Fig. 4; I A a) comprises most of the species of Sobralia section Sobralia, which is sister to an Elleanthus plus Sobralia d'orbignyana and S. flava subclade. Sister to this clade is Sertifera. Clade "I A b" (Fig. 4) is composed of the samples of section Abbreviatae section with Sobralia undatocarinata.

The noted close relationship between $S$. dorbignyana-S. flava and Elleanthus is also well observed on the matK tree (Fig. 5). In this case, the taxa also create a distinguishable group ( $\mathrm{PP}=89$ ) (Fig. 5; I B). It is here associated with a large assemblage created by all sections of Sobralia except the nominal one (Fig. 5; I A). Section Sobralia is divided into two clades. One of them is composed of S. altissima, caloglossa, S. cattleya, S. dichotoma, S. hirtzii and $S$. roezlii (Fig. 5; II), and it is a basal group for mentioned clade I. Sobralia portillae samples create another group (Fig. 5; III) which is a basal clade for all other Sobraliae except Sertifera (Fig. 5; IV). A branch composed of this taxon sample is in basal position in relation with all other members of the tribe.

\section{Discussion}

\section{Historical background}

In connection with the visible morphological diversity of Sobralia species, there have been a few attempts at its infrageneric classification, dividing it into morphologically homogenous groups (Table 1). Lindley (1854) split the genus into three sections. Section "A"-according to Lindley's terminology_embraced species with "flowers in a naked flexuose raceme," section "B" was created for species with "flowers in a flexuose raceme, with distant cymbiform foliaceous bracts," the third section, "C," grouped species characterized by "flowers in a cone-like head, or naked." In 1873, Reichenbach verified this classification and proposed the division into two sectionsEusobralia characterized by terminal inflorescence and Brasolia producing lateral inflorescence. The next classification was published by Brieger in 1983, who accepted the groups appointed by Reichenbach. He divided Eusobralia into two sections-Racemosae Brieger (with elongated inflorescences) and Abbreviatae Brieger (with abbreviated inflorescence) and renamed Brasolia as Sobralia. The author also added further sections: Intermediae Brieger with small flowers and small, terminal inflorescences; and section Globosae Brieger which includes species characterized by narrow, acuminate leaves, a basally narrow column and terminal inflorescence consisting of a cluster of floral bracts, which progressively elongates in length as flowers are produced.

The most recent treatment of Sobralia was published by Dressler in 2002. The author generally confirmed Brieger's sectional classification. However, Dressler stated that sections Sobralia and Racemosae should not be defined on the basis of the inflorescence position because members of section Sobralia may also produce terminal inflorescences. Calaway Dodson suggested to Dressler that a much better character differentiating the two groups is the size of the floral bracts. Species of the section Sobralia are characterized by floral bracts distinctly shorter than the ovary, while species of the Racemosae section have long, cymbiform floral bracts, distinctly exceeding the ovaries. Dressler also indicated that there are species (e.g., $S$. luteola Rolfe and S. valida Rolfe) and groups of species (e.g., S. macrophylla-complex and S. undatocarinatacomplex) which do not fit into any of Brieger's sections, 


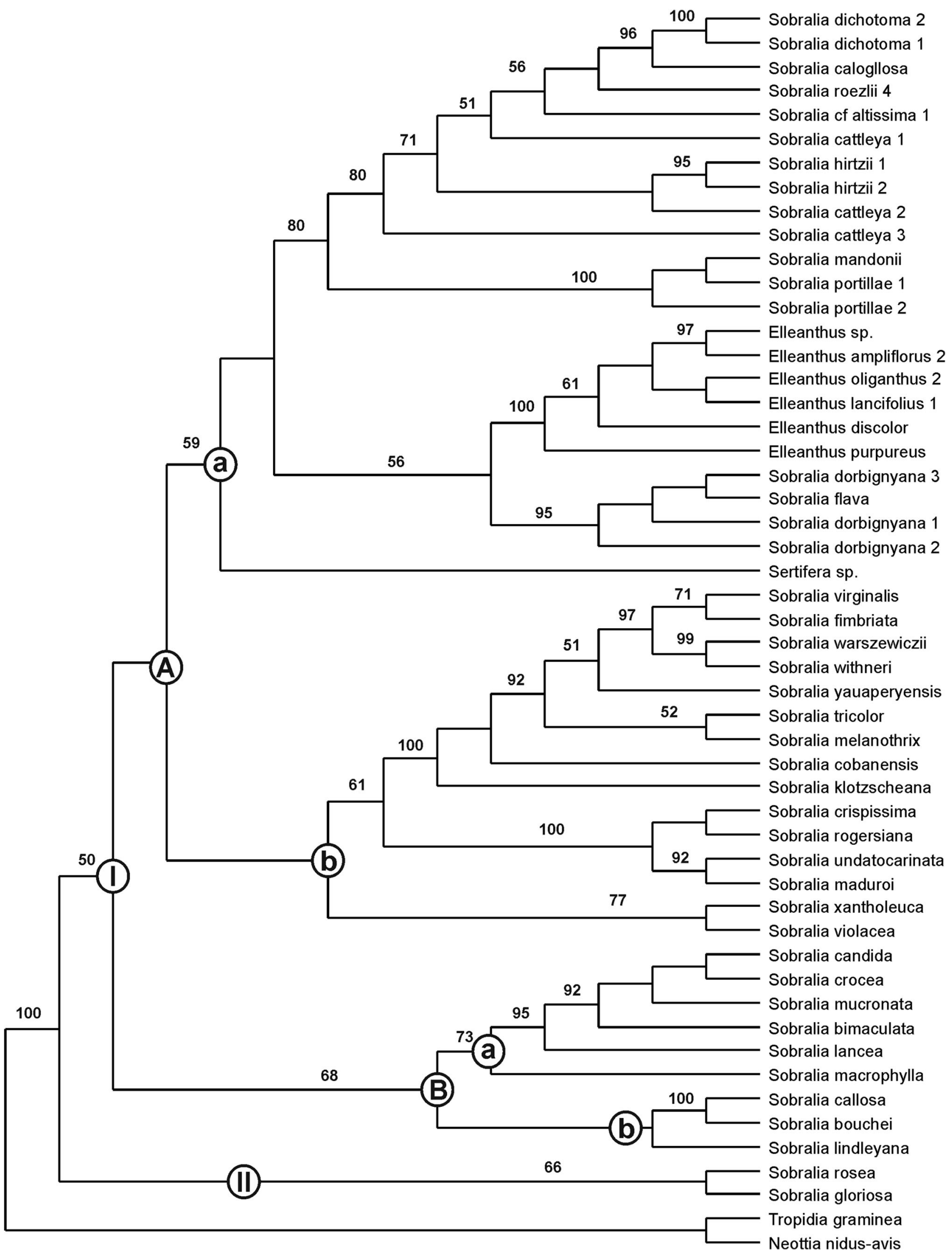


4Fig. 4 Majority-rule consensus of 7500 trees obtained in Bayesian analysis of $X d h$ gene for Sobralieae. The branches length is shown above. Values below branches represent bootstrap support $(\geq 50 \%)$ from 1000 replicates and posteriori probabilities $(\geq 50 \%)(\mathrm{bp} / \mathrm{pp})$

but he refrained from proposing further sectional names without supporting molecular evidence.

The problem with the infrageneric classification of Sobralia became even more complicated. In the light of a molecular study of Sobralieae, Neubig et al. (2011) and Dressler et al. (2011) noted that most species of the nominal section form a paraphyletic grade, which is more closely related to Elleanthus, Epilyna and Sertifera than to the other Sobralia sections. Additionally, members of the section Sobralia are easily distinguishable from other species of the genus. The authors concluded that the splitting of the genus is imminent. The problem is that the much smaller nominal section would have to be left as Sobralia with $S$. dichotoma as the generic type and all other species would have to be transferred to Cyathoglottis Poepp. \& Endl.- the oldest available synonym of Sobralia. Taking into account the number of species that would have to be transferred, and the fact that many of them are common in cultivation as ornamental plants, such reorganization of the group could cause confusion. That is why Dressler et al. (2011) proposed to conserve Sobralia with S. biflora Ruiz \& Pav. as the conserved type. Unfortunately, no further nomenclatural changes within the genus have been made since the publication of the proposal by Dressler et al. (2011).

\section{Sobralia section Sobralia-Elleanthus}

Until recently, it appeared that DNA fragment sequencing would enable the reconstruction of the phylogeny of organisms with a high degree of accuracy. In many cases, the data obtained from any sources other than genetic material began to be discarded. Numerous articles presenting a completely new approach to the taxonomy of plants and other organisms were published (e.g., Chase et al. 2000; Asmussen et al. 2006; Friesen et al. 2006; Lefébure et al. 2006), usually being simple transformations of phylogenetic tree into classification system, even though relatively often it was difficult or even impossible to define molecular taxa in terms of their morphology. The similarity between molecular marker sequences in morphologically different species groups-Sobralia sect. Sobralia and Elleanthus, which together form a common phylogenetic branch (Fig. 3, 4, 6) is one such case.

The two groups, although similar in habit, differ distinctly in position and structure of the inflorescence and in the size and morphology of their flowers. While the inflorescence of Elleanthus is always terminal and unbranched, those of Sobralia sect. Sobralia are most often axillary and loosely branched racemes. The floral bracts of Elleanthus are usually longer than the flower and often brightly colored while the floral bracts of Sobralia sect. Sobralia are small and inconspicuous, much shorter than their relatively long ovaries. Furthermore, the flowers of this section are distinctly larger with a more spreading perianth. In addition, the labellum is furnished with longitudinal keels running from the base to the apex. The protuberances are most often deeply fimbriate and form a cushion of fimbriae in the apical part of the labellum. Such keels are not observed in Elleanthus species. On the other hand, the base of the labellum in sect. Sobralia is not ornamented by a pair of fleshy calli as it is commonly observed in Sobralia section Abbreviatae Brieger, which forms a separate clade in relation to $\mathrm{El}$ leanthus-Sobralia sect. Sobralia clade in phylogenetic analyses. In Elleanthus, subglobose calli are present and are often very large compared to the size of the labellum. The two groups differ also in the structure of gynostemium, especially pollinia (e.g., four pollinia composed of grains loosely held together by the elastoviscin in Sobralia vs. eight coherent pollinia in Elleanthus).

There are phenomena that can generate a disturbance in the topology of the phylogenetic tree. It is worth to mention the paper published by Stegemann et al. (2012) concerning horizontal gene transfer (HGT), which sheds new light on an incongruity between molecular datasets of various origin. The authors discovered that chloroplast genomes can be readily transferred between relatively closely related species by natural grafting, thus also providing a possible explanation for why chloroplast sequences frequently provide trees that disagree with canonical phylogeny and/ or trees constructed with nuclear markers. Although we do not know of any reports concerning HGT in Andean orchids, this process cannot be excluded in this case.

Taking into consideration the aforementioned reports, both HGT and ancestral hybridization might be responsible for the topology of phylogenetic trees and the puzzling position of some species. In our opinion, this could be the case of Sobralia and Elleanthus. It is worth mentioning that intergeneric hybrids, neither natural nor artificial, between species of Sobralia and Elleanthus are known. Of course, it does not mean that such hybridization could not take place in the past. Reconstruction of evolutionary history in general strongly affected by reticulation and polyploidization is definitely not an easy task. Importantly, Sobralia and Elleanthus species inhabit similar geographical regions and plant communities, i.e., Andean humid montane and premontane forests, often growing together, which makes gene/genome transfer possible. The Andes are a well-known center of biodiversity, where many taxa have proliferated due to fluctuating geological, environmental and biological conditions (Bates et al. 2008; Richter et al. 2009). Of course, it could be one of many other 


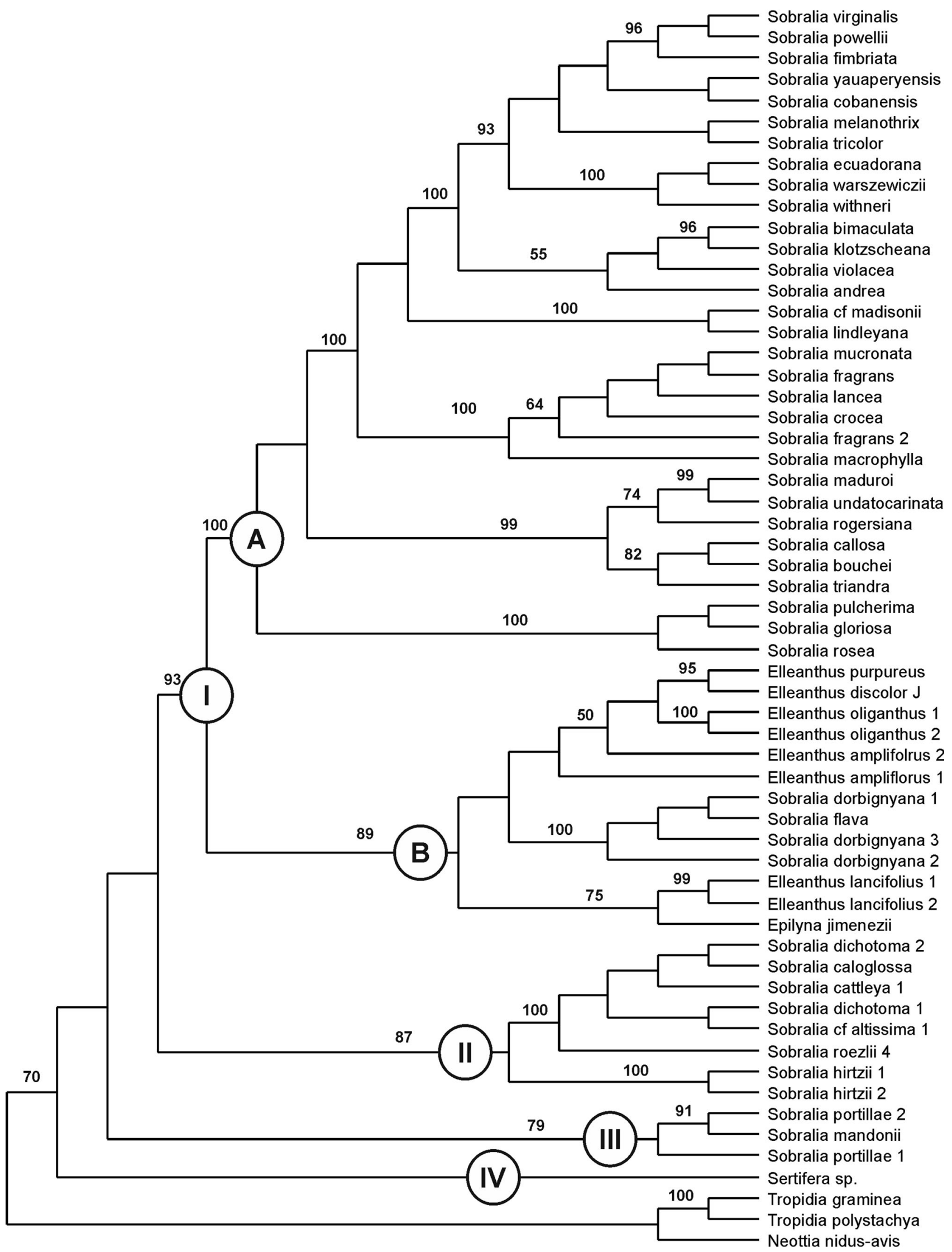


4Fig. 5 Majority-rule consensus of 7500 trees obtained in Bayesian analysis of part of matK gene for Sobralieae. The branches length is shown above and bootstrap support $(\geq 50 \%)$ versus posteriori probabilities $(\geq 50 \%)$ below the branch (bp/pp)

explanations for the observed topology of the obtained phylogenetic tree.

\section{Sobralia polyphyly}

The polyphyly of Sobralia suggests that the genus requires some taxonomical reassignments. One solution is to combine Sobralia sect. Sobralia with Elleanthus and other genera of Sobralieae. Such a new level of combining genera has already been proposed by Schuiteman and Chase (2015) in the case of Maxillaria Ruiz \& Pav. and related genera. However, such move would increase the confusion by obscuring these morphologically distinct taxa in a single, polymorphic genus that would be impossible to define morphologically. Another way to solve the problem is to raise the taxonomic status of the Sobralia sect. Sobralia to the generic level. Morphologically, the group is well separated from all other species of the genus. The
Fig. 6 Inflorescences and flowers of various Brasolia (ad) and Sobralia species (e-f): a b B. dichotoma (Ruiz and Pav.) Baranow, Dudek \& Szlach. (Photo by M. Kolanowska), c $B$. flava (Baranow \& Szlach.) Baranow, Dudek \& Szlach. (Photo by E. Hunt), d $B$. portillae (Christenson) Baranow, Dudek \& Szlach.; e $S$. rosea Poepp. \& Endl., section Racemosae Brieger, f $S$. decora Bateman, section Sobralia (Photos by L. Grobbler)
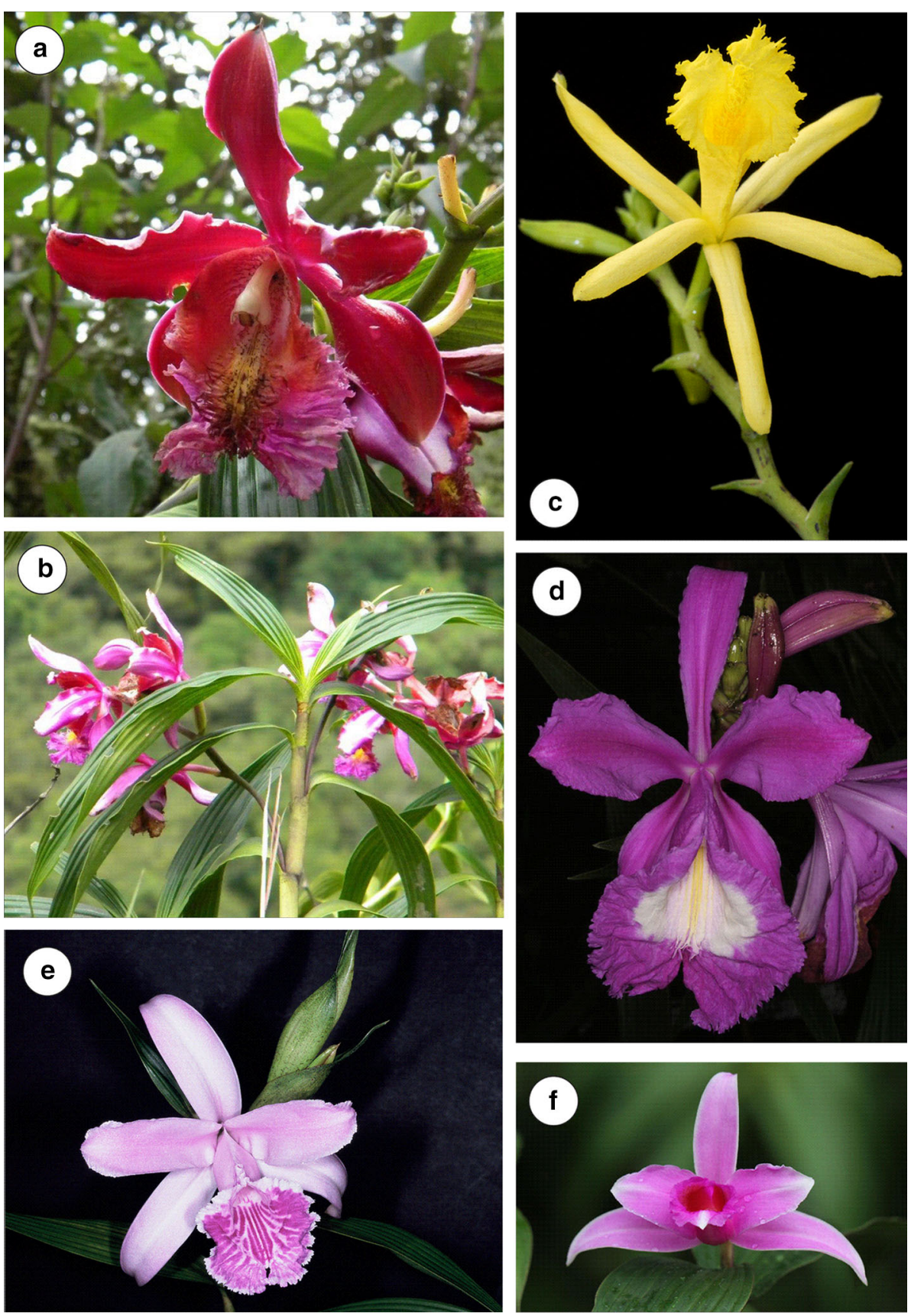

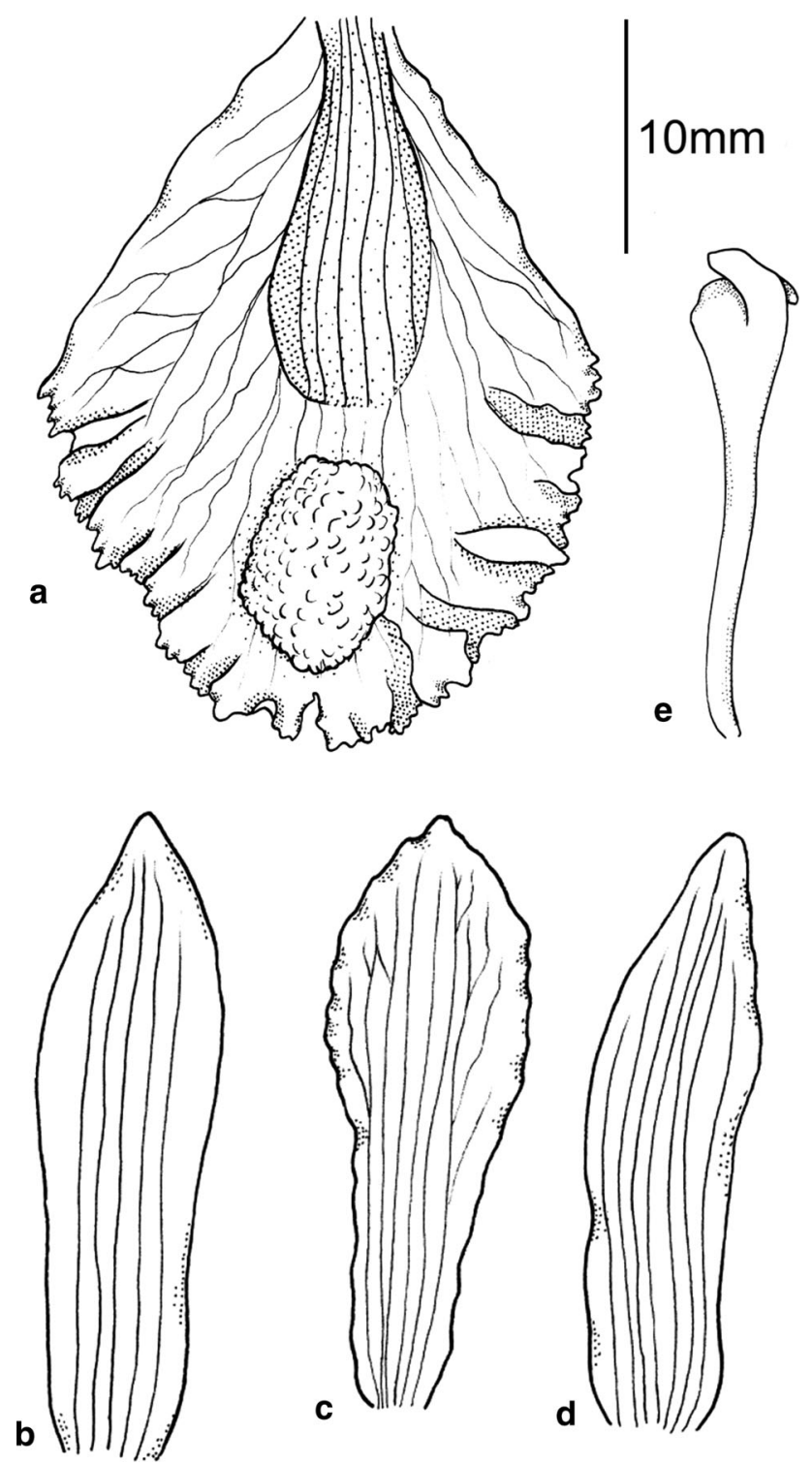

Fig. 7 Brasolia floribunda Baranow, Dudek \& Szlach. a Labellum, b dorsal sepal, c petal, d lateral sepal, e gynostemium (drawn by P. Baranow from the holotype)

elongated, often branched, in most cases axillary inflorescences (Fig. 7a) and tiny floral bracts allow distinguish the group easily. All other species of the genus always produce a terminal, unbranched inflorescence with relatively larger floral bracts and most often with one, two or occasionally several (S. undatocarinata-complex and S. luteola) flowers at a time (Fig. 7e-f). The flowers of the section Sobralia are also distinctive in most cases, and the labellum is furnished with strongly fimbriate keels running along the central nerves; in some species (e.g., S. dichotoma Ruiz \& Pav.) the fimbriae are grouped in the apical part of the labellum into a distinct, dense tuft (Fig. 7b). Such protuberances are characteristic for S. fimbriata Poepp. \& Endl. of sect. Abbreviatae. However, S. fimbriata produces flowers delicate in texture with deeply fimbriate margins, which distinguishes the species from representatives of the sect. Sobralia. In this case, the presence of the protuberances could be a result of convergence.

The only doubts associated with the idea of segregating section Sobralia from other taxa of Sobralieae are connected with the position of $S$. dorbignyana-S. flava complex (S. flava presented in Fig. 7c) and S. portillae (Fig. 7d) on the phylogenetic trees. Sobralia flava Baranow \& Szlach. was recently described (Baranow and Szlachetko 2017) as a result of the morphological study on Sobralia dorbignyana which turned out to be not one species but a group of similar but recognizable taxa. In this paper, we include the plant that was later established as a holotype of $S$. flava and other samples representing the complex named as $S$. dorbignyana 1, 2, 3 and N. It is possible that the specimens also represent $S$. flava, but it was impossible to verify their determination. It does not influence the interpretation of the results as we do not discuss the relations within the group here. Thus, we use the term S.dorbignyana-S. flava mentioning representatives of the group. Together with $S$. portillae, these species are well separated on most of the phylograms (except the $x d h$-based tree, where S. portillae and other species of the nominal section are joined together into a mutual clade). Moreover, $S$. dorbignyana-S. flava seems to be more closely related to Elleanthus than to other species of the section to which it is classified. This is surprising, as inflorescences, flowers and floral bracts of the species suggest that it is a typical representative of the nominal section. In Figs. 3, 4 and 5, Sobralia portillae samples form an assemblage with sample named as $S$. mandonii. We assume that it is incorrectly determined. Sobralia mandonii is actually treated as a synonym of $S$. dichotoma (see the taxonomic treatment) and other sample labeled as $S$. mandonii $\mathrm{N}$ is a part of the clade with $S$. dichotoma and other morphologically similar taxa (Fig. 3; B). However, we decided not to change the determinations of the specimens that were obtained from other sources than our own collection.

Maybe the fact that $S$. dorbignyana-S. flava and $S$. portillae are characterized by terminal inflorescences is support for the distinctness of the taxa. On the other hand, although the remaining species of section Sobralia usually produce axillary inflorescences, specimens with inflorescences borne from the stem apex can also be found. In this case, we are convinced that the nominal section of Sobralia should not be divided. However, the morphological and molecular distinctness of the whole section should be emphasized.

Therefore, we decided to split Sobralia into two distinct genera. The newly distinguished genus is the present-day section Sobralia. In the light of phylogenetic outcomes, the proposed taxon is paraphyletic, which 
means that its species have a common ancestor, but the taxon does not include all its descendants (e.g., Elleanthus). Monophyly in its broader definition describes groups with a common ancestry, including both paraphyletic and monophyletic groups (sensu Hennig 1950); therefore, Hörandl and Stuessy (2010) advocate returning to this broader definition of monophyly and, adopting Ashlock's term, holophyly for monophyly s.str. Paraphyly is a natural transition stage in the evolution of taxa (Hörandl and Stuessy 2010). According to Brummitt (2002), paraphyletic taxa are "products of the evolutionary process, which is left behind as evolution moves on to a new level of organization."

We realize that this is in conflict with commonly accepted phylogenetic methods which declare that monophyly s.str. should be the only criterion for grouping organisms. However, a somewhat analogical situation has been recognized within Coelogyne (Gravendeel et al. 2001). In this case, the authors interpreted the morphology of the studied species as not corresponding to the cladograms, probably as a result of convergent evolution and they decided to maintain polyphyletic Coelogyne. Kolanowska and Szlachetko (2016) postulate to maintain paraphyletic Odontoglossum.

Recognition of distinctive characters which have evolved in a group is essential for an understanding its evolution (Brummitt 2006). This point of view is shared by numerous other authors (Sosef 1997; Dias et al. 2005; Nordal and Stedje 2005) who state that traditional classification is the optimal tool for cataloging biodiversity and requires recognition of paraphyletic taxa. We decided to follow the Darwinian (evolutionary) classification, which requires consideration of two criteria: similarity and common descent. The approach will allow us to propose a classification based on the phylogenetic relationships, but at the same time it will be practical—with clearly defined and recognizable units.

\section{Taxonomic treatment}

Following the suggestion by Dressler et al. (2011), we accept Reichenbach's Brasolia as the generic name for the present Sobralia section Sobralia. The type species of Brasolia should be Sobralia dichotoma, which actually is the type species of Sobralia sensu lato. Therefore, the newly described taxon could be nomenclaturally superfluous, because it would replace Sobralia as currently typified. This means that even after Dresslers' proposition to conserve Sobralia biflora Ruiz \& Pav. as a type of Sobralia (2011) is accepted, the name Brasolia would be illegitimate. Thankfully, according to Art. 52.3 of ICN (McNeill et al. 2012) "a name that was nomenclaturally superfluous when published is not illegitimate on account of its superfluity if it has a basionym." As Sobralia [unranked] Brasolia Rchb.f. (in Fl. Serres Jard. Eur. 8: 247: 1853) is a legitimate name with $S$. dichotoma as the sole species and hence the original type, it is possible to publish the generic name Brasolia based on Reichenbach's subdivision of Sobralia, and, although it is technically incorrect at the moment, it will become automatically correct after the conservation of Sobralia with S. biflora as a type is finally approved in July 2017 during the next International Botanical Congress. As the proposal has already been recommended for acceptance by the Nomenclature Committee for Vascular Plants (Applenquist 2012), it is just a matter of formality as the proposal and the Committee's procedure are both perfectly in order. At the same time, the section Abbreviatae, as a group from which the new type species of Sobralia was selected (S. biflora Ruiz \& Pav.), becomes a taxonomic synonym of section Sobralia (Dressler et al. 2011). Therefore, there is no necessity to transfer over 100 species of Sobralia sensu stricto to $C y$ athoglottis Poepp. \& Endl.- the second oldest generic name available for Sobralia.

Brasolia (Rchb.f.) Baranow, Dudek \& Szlach., gen. nov. $\equiv$ Sobralia [unranked] Brasolia Rchb.f., Fl. Serres Jard. Eur. 8: 247. Oct. 1853.-TYPE: Brasolia dichotoma (Ruiz \& Pav.) Baranow, Dudek \& Szlach.

Diagnosis: Tall erect plants with reed-like, unbranched stems. Leaves narrowly lanceolate to ovate, distichous, often somewhat plicate. Inflorescence axillary from the base of one of uppermost leaves or terminal, few- to manyflowered, often branched, with distinct internodes of rachis and its branches. Floral bracts much shorter than pedicellate ovary, triangular, acute. Flowers often somewhat fleshy, persistent, white, pink, reddish, purple, violet or brownish, often with contrasting colored fimbriate keels on the labellum, opening simultaneously or successively but always more than one at a time on the inflorescence, the developing floral buds visible.

Brasolia altissima (D.E.Benn. \& Christenson) Baranow, Dudek \& Szlach., comb. nov. $\equiv$ Sobralia altissima D.E.Benn. \& Christenson, Orchids 68(11): 1112 (1999).TYPE: Peru, Huancavelica, Tajacaya, Huachocolpa, Inquilpata, 2800-1900 m a. s. 1., 18 Feb 1999, Leon et al. 2962 (holotype: originally deposited at Herb. Bennettianum, now at MOL [n.v.]; isotype: MOL [n.v.]).

Brasolia boliviensis (Schltr.) Baranow, Dudek \& Szlach., comb. nov. $\equiv$ Sobralia boliviensis Schltr., Repert. Spec. Nov. Regni Veg. 12: 491. 1913.-TYPE: Bolivia, "In Buschwald der Waldgrenze bei Tocorani. 2900 m a. s. 1.", 
30 Jun 1911, Herzog 2311 (lectotype designated here: L329608!; isolectotype: S [n.v.]).

= Sobralia alstroemerioides Schltr., Repert. Spec. Nov. Regni Veg. Beih. 9: 43. 1921.-TYPE: Peru, Cuzco, near Sandía, on cliffs, Weberbauer 558 (not localized).

Brasolia caloglossa (Schltr.) Baranow, Dudek \& Szlach., comb. nov. $\equiv$ Sobralia caloglossa Schltr., Repert. Spec. Nov. Regni Veg.27: 31. 1929.-TYPE: Bolivia, La Paz, Tipuani Valley, Hacienda Casana, 1400 m a. s. 1., 30 Aug 1920, Buchtien 7210 ( $\mathrm{B} \dagger$; lectotype designated by Christenson (1996): US93883!; isolectotype: Z [n.v.]).

Brasolia cattleya (Rchb.f.) Baranow, Dudek \& Szlach., comb. nov. = Sobralia cattleya Rchb.f., Gard. Chron. 1: 72. 1877.-TYPE: Colombia, Ocana, s.loc., Carder and Schuttleworth s.n. (holotype: WR19212!)

Notes: The type collection consists of one specimen only. In such cases, the sole plant is called holotype, no matter when the taxon was described (see ICN, Chapter II, Article 9.1, McNeill et al. 2012)

Brasolia ciliata (C.Presl) Baranow, Dudek \& Szlach., comb. nov. $\equiv$ Bletia ciliata C.Presl, Reliq. Haenk. 1(2): 99. 1827.-TYPE: Peru, Huánuco, Haenke s.n. (PRC [n.v.]). $\equiv$ Sobralia ciliata (C.Presl) C.Schweinf. and Foldats, Fl. Venezuela 15(1): 175. 1969.

= Sobralia porphyrocharis Rchb.f., Xenia Orchid. 2: 177. 1873.-TYPE: Ecuador, without proper locality, Pearce 31 (holotype: W19191!).

Brasolia dichotoma (Ruiz \& Pav.) Baranow, Dudek \& Szlach., comb. nov. $\equiv$ Sobralia dichotoma Ruiz \& Pav., Syst. Veg. Fl. Peruv. Chil. 1: 232. 1798.-TYPE: Peru, Huánuco, Habitat abunde in nemoribus Muña, Pozuzo et Chinchao per runcationes in locis calidis et saxosis, Ruiz and Pavón s.n. (lectotype: MA810836!; isolectotypes: G [n.v.], MA810837!, MA810838!, MA810839!, MA810840!, MA810841!, MA810842!, P441683!, P441685!). $\equiv$ Cattleya dichotoma (Ruiz \& Pav.) Beer, Prakt. Stud. Orchid. 215. 1854.

=Sobralia mandonii Rchb.f. Xenia Orchid. 2: 175, t. 175, f. I, 1. 1873.-TYPE: [Bolivia. La Paz] Larecaja, Viccinis Sorata, colle Cataguata et valle Challasuya, in scopulosis, $2700 \mathrm{~m}$ a. s. 1. G. Mandon 1170 (lectotype: W19193!; isolectotypes: AMES00104310!, AMES00104309!, BM61264!, K364490!, P441737!, U!, W19196!).

= Sobralia mandonii Rchb.f. f. coerulea Christenson, Orchids (West Palm Beach) 71(11): 998. 2002.-TYPE: Peru, Amazonas, kilometer marker 325 along road to Moyobamba to Pomocochas, $1980 \mathrm{~m}$ a. s. 1., Christenson et al. 2010 (holotype: CUZ [n.v.]; isotypes: HAO [n.v.], USM [n.v.]).
Brasolia dorbignyana (Rchb.f.) Baranow, Dudek \& Szlach., comb. nov. $\equiv$ Sobralia dorbignyana Rchb.f., Xenia Orchid. 2: 179. 1873.-TYPE: Bolivia, N. Yungas, d'Orbigny 477 (holotype: W19207!; isotype: P441668!).

Brasolia flava (Baranow \& Szlach.) Baranow, Dudek \& Szlach., comb. nov. $\equiv$ Sobralia flava Baranow \& Szlach. Nordic J Bot 35: 40. 2017.--TYPE: Ecuador, ZamoraChinchipe, along road from Zumba to San Ignacio, close to La Balza village, 2008, cult. Ecuagenera sub Szlachetko 8537 (holotype: UGDA, spirit!, isotype: QCA!).

Brasolia floribunda Rchb.f. ex Baranow, Dudek \& Szlach., sp nov. (Fig. 8)-TYPE: s.loc., Carden s.n. (holotype: W19190!)

Description: Inflorescence ca. $15 \mathrm{~cm}$ long, racemose, ca. 10-flowered. Floral bracts $9 \mathrm{~mm}$ long, triangular, acuminate. Pedicel and ovary $20 \mathrm{~mm}$ long. Flowers white, labellum purple below, yellow on the inner side. Dorsal sepal $30 \times 9 \mathrm{~mm}$, linear-oblanceolate, acute. Lateral sepal $30 \times 9 \mathrm{~mm}$, lanceolate, acute, slightly falcate. Petals $30 \times 10 \mathrm{~mm}$, spathulate, acute, margins slightly irregularly crenate and undulate in apical half, acute. Labellum $32 \times 23 \mathrm{~mm}$, ovate, emarginate, deeply concave basally, without basal calli and keels running along the nerves. The only protuberances are the hairs forming an ovoid cushion composed of a thickening strongly wrinkled on its surface. The margins of labellum are entire in basal half, erose and undulate in apical half. Gynostemium $18 \mathrm{~mm}$ long, slender as for the genus. Apical stelidia relatively long, distinctle exceeding the column apex, falcate, rounded.

Diagnosis: Similar with Sobralia mutisii Ortiz in white sepals and petals reminds. However, it can be distinguished other species of the genus by long-acuminate floral bracts, lack of fimbriate keels running along the central nerves of labellum, the presence of cushion of dense trichomes in the center of apical half of labellum and relatively slender gynostemium with long and distinct apical stelidia.

Distribution area: No data

Habitats: No data

Additional specimens examined: Known of the type collection only.

Notes: The species by its white sepals and petals reminds $S$. mutisii Ortiz. However, the plant differs from other species of the genus in having long-acuminate floral bracts, in lack of fimbriate keels running along the central nerves of labellum, in presence of cushion of dense trichomes in the center of apical half of labellum and in relatively slender 
gynostemium with long and distinct, exceeding the column apex apical stelidia.

The species was discovered by Reichenbach, who named it as Sobralia floribunda. However, the author left the name on the herbarium label of the type specimen only and he never formally published his discovery.

Brasolia hirtzii (Dodson) Baranow, Dudek \& Szlach., comb. nov. 三 Sobralia hirtzii Dodson, Nat. Ecuad. Orch. 5: 1180, pl. 2209-10. 2004.-TYPE: Ecuador, Imbabura, Ibarra to Lita, Guallupe to Buenos Aires, km 32, $2200 \mathrm{~m}$ a. s. 1., 16 Mar 1991, Hirtz et al. 5215 (holotype: RPSC [n.v.]).

Brasolia kermesina (Garay) Baranow, Dudek \& Szlach., comb. nov. 三 Sobralia kermesina Garay, Canad. J. Bot. 34: 242, fig. 10A. 1956.-TYPE: Ecuador, Loja, Hda. Guaycopambam, on Río Guaycopamba, $20 \mathrm{~km}$ south of Vilcambamba, 1750-1800 m a. s. 1., 15 Feb 1945, Fosberg and Giler 23063 (holotype: US93884!; isotype: AMES287092!).

Brasolia mutisii (P.Ortiz) Baranow, Dudek \& Szlach., comb. nov. $\equiv$ Sobralia mutisii P.Ortiz, Orquideologia 23(1): 50 (-54, 60-62; figs.). 2004.-TYPE: Plate No. 528-reproduction of a drawing made for the Real Expedicion Botanica del Nuevo Reino de Granada (holotype: MA!).

Brasolia odorata (Schltr.) Baranow, Dudek \& Szlach., comb. nov. 三 Sobralia odorata Schltr., Repert. Spec. Nov. Regni Veg. Beih. 27: 128. 1924._TYPE: Colombia, Cundinamarca, Cuchilla de Riachon, ca. 1400 m. Bis 5 m hohe Gebusche bildend, bluhend Anfang Mar 1922, Schultze 12 (B十); Cundinamarca: Cordillera Oriental, Guavio River Valley, $4 \mathrm{~km}$ north of Ubala, $1700 \mathrm{~m}$ a. s. 1., 29 May 1944, Grant \& Fosberg 9370 (neotype designated here: COL301750!).

Brasolia oliva-estevae (Carnevali \& I.Ramírez) Baranow, Dudek \& Szlach., comb. nov. 三 Sobralia olivaestevae Carnevali \& I.Ramírez, Ann. Missouri Bot. Gard. 77: 556. 1990.-TYPE: Venezuela, Bolivar, Parque Nacional Canaima, La Escalera, bosque nublado enano alrededor del km 125 al S de El Dorado, 1300 m a. s. 1., 30 Aug-8 Sep 1987, Ramirez, Carnevali and Oliva-Esteva 150 (holotype: VEN [n.v.]).

Brasolia rigidissima (Linden ex Rchb.f.) Baranow, Dudek \& Szlach., comb. nov. $\equiv$ Sobralia rigidissima Linden ex Rchb.f., Bonplandia 2: 278. 1854.-TYPE: Colombia, Norte de Santander, Ocaña, 2438 m a. s. 1., 1846-1852, Schlim 36 (lectotype designated here: W!19189; isolectotypes: BR658918, K364488, K-L!, P441742!, drawing of the type: AMES!, photo of the type: AMES!).

Brasolia roezlii (Rchb.f.) Baranow, Dudek \& Szlach., comb. nov. $\equiv$ Sobralia roezlii Rchb.f., Xenia Orchid. 2: 178. 1873.-TYPE: Colombia, Medellin, Nueva Granada, Roezl 19217 (holotype: W19217!).

Brasolia scopulorum (Rchb.f.) Baranow, Dudek \& Szlach., comb. nov. 三 Sobralia scopulorum Rchb.f., Xenia Orchid. 2: 176. 1873.-TYPE: Bolivia, Larecaja, Viccinis Quiabaya, prope Motoata, in scopuloris, $3000 \mathrm{~m}$ a. s. 1., May 1856, Mandon 1171 (lectotype designated here: W19187!; isolectotype: P441749!).

Brasolia semperflorens (Kraenzl.) Baranow, Dudek \& Szlach., comb. nov. 三 Sobralia semperflorens Kraenzl., Vierteljahrsschr. Naturf. Ges. Zürich 60: 428. 1915. 三 Sobralia parviflora L.O. Williams, Lilloa 3: 475. 1938.-TYPE: Bolivia, without precise locality, Bang 2290 (lectotype designated by Baranow and Szlachetko (2017): W1117!; isolectotypes: AMES00104318!, AMES00104319!, MO2157665!, K-drawing, Z n.v.).

Brasolia sobralioides (Kraenzl.) Baranow, Dudek \& Szlach., comb. nov. 三 Chlorea sobralioides Kraenzl. Notizbl. Bot. Gart. Berlin-Dahlem 7: 447. 1921. $\equiv$ Sobralia sobralioides (Kraenzl) Garay, Fl. Ecuador 9: 133. 1978.-TYPE: Colombia, Cundinamarca, Cordillera del Sargento, Kalbreyer 2043 (neotype designated by Baranow and Szlachetko 2017: AMES110024!, isoneotypes: COL52910!, US344190!). 三 Sobralia kalbreyeri Schltr., Notizbl. Bot. Gart. Berlin-Dahlem 7: 531. 1921.

Brasolia speciosa (C.Schweinf.) Baranow, Dudek \& Szlach., comb. nov. 三 Sobralia speciosa C.Schweinf., Bot. Mus. Leafl. 19: 198. 1961.-TYPE: Venezuela, Amazonas, Cerro de la Neblina, Rio Yatua, near Cumbre Camp, 1-2 m tall. 1800 m a. s. 1., 19 Nov 1957, Maguire, Wurdack and Maguire 42142 (holotype: AMES104332!; isotypes: K364487! P441762!, U5424!).

Brasolia stenophylla (Lindl.) Baranow, Dudek \& Szlach., comb. nov. 三 Sobralia stenophylla Lindl. Fol. Orchid. Sobralia: 2: 1854._-TYPE: Guyana, Schomburgk s.n. (lectotype designated by Szlachetko et al. 2012: K-L!).

Brasolia uribei (P.Ortiz) Baranow, Dudek \& Szlach., comb. nov. $\equiv$ Sobralia uribei P.Ortiz, Orquideologia 19(3): 10. 1994.-TYPE: Colombia, Santander, Mesa de los Santos, $1600 \mathrm{~m}$ a. s. 1., 4 Apr 1961, Uribe 3661 (holotype: COL88797!) 
Brasolia weberbaueriana (Kraenzl.) Baranow, Dudek \& Szlach., comb. nov. 三 Sobralia weberbaueriana Kraenzl., Repert. Spec. Nov. Regni Veg. 1: 188. 1905.-TYPE: Peru, Weberbauer 2076 ( $\mathrm{B} \uparrow$; lectotype designated here: MO348589 [photo!])

\section{Incertae saedis}

Sobralia bonplandii Rchb.f.-TYPE: s.loc., Bonpland s.n. (W R19204!).

Notes: The species was never formally described. The only material representing it is the specimen kept at $\mathrm{W}$ herbarium with a label left by Reichenbach who named it $S$. bonplandii. The specimen is incomplete-there is only one, partially destroyed flower and a drawing of its labellum on the herbarium sheet. With such poor material, we have no evidence that it represents an undescribed species. Thus, we decided to place it in Incaerte seadis section without validating it. The flower structure suggests that the plant represents Brasolia genus.

Acknowledgements We would like to express our gratitude to John McNeill for his help with the interpretation of ICN rules concerning the proposed taxonomical changes. We would also like to thank Fredy Archila, John Romano and Bruce Rogers, who kindly sent us some of the samples used in the molecular analyses. We are grateful to Marta Kolanowska, Eric Hunt and Lourens Grobbler for their kind agreement for using their photographs in the manuscript.

Funding This work was supported by Polish National Science Centre [8124/B/PO1/2011/40]; The University of Gdansk, Faculty of Biology [538-L150-B919-15].

\section{Compliance with ethical standards}

Conflict of interest The authors declare that they have no conflict of interest.

Open Access This article is distributed under the terms of the Creative Commons Attribution 4.0 International License (http://creative commons.org/licenses/by/4.0/), which permits unrestricted use, distribution, and reproduction in any medium, provided you give appropriate credit to the original author(s) and the source, provide a link to the Creative Commons license, and indicate if changes were made.

\section{Information on Electronic Supplementary Material}

Online Resource 1. Matrix of features and their states used for morphological analyses.

Online Resource 2. List of DNA sequences used in the study.

Online Resource 3. ITS data matrix used in the study.

Online Resource 4. $X d h$ data matrix used in the study.

Online Resource 5. mat $\mathrm{K}$ data matrix used in the study.

Online Resource 6. Bayesian 50\% majority-rule tree for Sobralieae from ITS1-5.8S-ITS2 sequences.

Online Resource 7. Majority-rule consensus of 7500 trees obtained in Bayesian analysis of $X d h$ gene.
Online Resource 8. Majority-rule consensus of 7500 trees obtained in Bayesian analysis of part of mat $\mathrm{K}$ gene.

\section{References}

Applenquist WL (2012) Report of the nomenclature for vascular plants. Taxon 61:1108-1117

Asmussen CB, Dransfield J, Deickmann V, Barfod AS, Pintaud JC, Baker WJ (2006) A new subfamily classification of the palm family (Arecaceae): evidence from plastid DNA. Bot J Linn Soc 151:15-38. doi:10.1111/j.1095-8339.2006.00521.x

Baranow P, Szlachetko DL (2017) The taxonomic study of the Sobralia dorbignyana complex (Orchidaceae). Nordic J Bot 35:38-44. doi:10.1111/njb.01271

Bates JM, Cadena CD, Tello JG, Brumfield RT (2008) Diversification in the neotropics: phylogenetic patterns and historical processes. Ornitol Neotrop 19:427-432

Brieger FG (1983) Subtribus Sobraliinae. In: Brieger FG, Maatsch R, Senghas K (eds) Die Orchideen I, vol 13. Verlag Paul Parey, Lieferung, pp 780-800

Brummitt RK (2002) How to chop up a tree. Taxon 51:31-41. doi:10. $2307 / 1554961$

Brummitt RK (2006) Am I a bony fish? Taxon 55:268-269. doi:10. 2307/25065576

Chase MW, Hills HH (1991) Silica gel: an ideal material for field preservation of leaf samples for DNA studies. Taxon 40:215-220. doi:10.2307/1222975

Chase MW, Soltis DE, Soltis PS, Rudall PJ, Fay MF, Hahn WJ et al (2000) Higher-level systematics of the monocotyledons: an assessment of current knowledge and a new classification. In: Wilson KL, Morrison DA (eds) Systematics and evolution of monocots. CSIRO Publishing, Collingwood, pp 3-16

Christenson EA (1996) Notes on neotropical Orchidaceae II. Lindleyana 11:12-26

Cuénoud P, Savolainen V, Chatrou LW, Powell M, Grayer RJ, Chase MW (2002) Molecular phylogenetics of Caryophyllales based on nuclear $18 \mathrm{~S} \mathrm{rDNA}$ and plastid $r b c \mathrm{~L}$, atpB and $m a t \mathrm{~K}$ DNA sequences. Amer J Bot 89:132-144. doi:10.3732/ajb.89. 1.132

Dias P, Assis LCS, Udulutsch RG (2005) Monophyly vs. paraphyly in plant systematics. Taxon 54:1039-1040. doi:10.2307/ 25065489

Douzery EJP, Pridgeon AM, Kores P, Linder HP, Kurzweil H, Chase MW (1999) Molecular Phylogenetics of Disae (Orchidaceae): a contribution from nuclear ribosomal ITS sequences. Amer J Bot 86:887-899

Dressler RL (1981) The orchids: natural history and classification. Harvard University Press, Cambridge, doi:10.2307/1219717

Dressler RL (1993) Phylogeny and classification of the Orchid Family. Dioscorides Press, Portland

Dressler RL (2002) The major sections or groups within Sobralia, with four new species from Panama and Costa Rica, $S$. crispissima, S. gloriana, S. mariannae and S. nutans. Lankesteriana 5:9-15. doi:10.15517/lank.v2i3.23088

Dressler RL, Blanco MA, Pupulin F, Neubig KM (2011) Proposal to conserve the name Sobralia (Orchidaceae) with a conserved type. Taxon 60:907-908

Drummond AJ, Suchard MA, Xie D, Rambaut A (2012) Bayesian phylogenetics with BEAUti and the BEAST 1.7. Molec Biol Evol 29:1969-1973. doi:10.1093/molbev/mss075

Dudek M, Szlachetko DL (2010) New combinations in subtribe Elleanthiinae (Orchidaceae, Epidendroideae). Richardiana 11:1-12 
Erixon P, Svennblad B, Britton T, Oxelman B (2003) Reliability of Bayesian posterior probabilities and bootstrap frequencies in phylogenetics. Syst Biol 52:665-673. doi:10.1080/10635150390235485

Felsenstein J (1985) Confidence limits on phylogenies: an approach using the bootstrap. Evolution 39:783-791. doi:10.2307/ 2408678

Fitch WM (1971) Toward defining the course of evolution: minimal change for a specific tree topology. Syst Zool 20:406-416. doi: $10.2307 / 2412116$

Friesen N, Fritsch RM, Blattner FR (2006) Phylogeny and new intrageneric classification of Allium L. (Alliaceae) based on nuclear ribosomal DNA ITS sequences. Aliso 22:372-395

Galtier N, Gouy M, Gautier C (1996) SeaView and Phylo_win, two graphic tools for sequence alignment and molecular phylogeny. Bioinformatics 12:543-548. doi:10.1093/bioinformatics/12.6.543

Górniak M, Paun O, Chase MW (2011) Phylogenetic relationships within Orchidaceae based on a low-copy nuclear coding gene, Xdh: congruence with organellar and nuclear ribosomal DNA results. Molec Phylogen Evol 56:784-795. doi:10.1016/j.ympev. 2010.03.003

Gravendeel B, Chase WM, de Vogel EF, Roos MC, Mes TH, Bachmann K (2001) Molecular phylogeny of Coelogyne (Epidendroideae; Orchidaceae) based on plastid RFLPS, matK, and nuclear ribosomal ITS sequences: evidence for polyphyly. Amer J Bot 88:1915-1927. doi:10.2307/3558367

Hammer $\varnothing$, Harper DAT, Ryan PD (2001) PAST: paleontological statistics software package for education and data analysis. Palaeontol Electron 4:1-9

Hennig W (1950) Grundzüge einer Theorie der Phylogenetischen Systematik. Deutscher Zentralverlag, Berlin

Hörandl E, Stuessy TF (2010) Paraphyletic groups as natural units of biological classification. Taxon 59:1641-1653

Kolanowska M, Szlachetko DL (2016) Problems with generic delimitation in the Odontoglossum complex (Orchidaceae, Oncidiinae) and an attempt for a solution. Pl Syst Evol 302:203-217. doi:10.1007/s00606-015-1254-6

Kores PJ, Molvray M, Weston PH, Hopper SD, Brown AP, Cameron KM, Chase MW (2001) A phylogenetic analysis of Diurideae (Orchidaceae) based on plastid sequence data. Amer J Bot 88:1903-1914. doi:10.2307/3558366

Lefébure T, Douady CJ, Gouy M, Gibert J (2006) Relationship between morphological taxonomy and molecular divergence within Crustacea: proposal of a molecular threshold to help species delimitation. Molec Phylogen Evol 40:435-447. doi:10. 1016/j.ympev.2006.03.014

Lindley J (1854) Folia Orchidacea, Sobralia. J. Matthews, London

McNeill J, Barrie FR, Buck WR, Demoulin V, Greuter W, Hawksworth DL et al (2012) International code of nomenclature for algae, fungi and plants (Melbourne Code). Regnum Veg 154:1-240

Molvary M, Kores PJ, Chase MW (2000) Polyphyly of mycoheterotrophic orchids and functional influences on floral and molecular characters. In: Morrison DA, Wilson KL (eds) Monocots: systematic and evolution. CSIRO Publishing, Collingwood, pp 441-448
Neubig KM (2011) Data from: preliminary molecular phylogenetics of Sobralia and relatives (Orchidaceae: Sobralieae). Dryad Digit Repos. doi:10.5061/dryad.s6t70

Neubig KM, Whitten WM, Blanco MA, Endara L, Williams NH, Koehler S (2011) Preliminary molecular phylogenetics of Sobralia and relatives (Orchidaceae: Sobralieae). Lankesteriana 11:307-317. doi:10.15517/lank.v11i3.18286

Nordal I, Stedje B (2005) Paraphyletic taxa should be accepted. Taxon 54:5-6. doi:10.2307/25065296

Nylander JAA (2004) MrModeltest v2. Program distributed by the author. Evolutionary Biology Centre, Uppsala University

Pridgeon AM, Cribb PJ, Chase MW, Rasmussen FN (1999) Genera Orchidacearum. Vol. 1: Apostasioideae and Cypripedioideae. Oxford University Press, New York

Pridgeon AM, Cribb PJ, Chase MW, Rasmussen FN (2005) Genera Orchidacearum. Vol. 4: Epidendroideae (Part 1). Oxford University Press, New York

Reichenbach HG (1853) Études sur les Orchidées. Fl Serres Jard Eur 8:243-248

Reichenbach HG (1873) Xenia Orchidacea, vol 2. F. A. Brockhaus, Leipzig

Richter M, Diertl KH, Emck P, Peters T, Beck E (2009) Reasons for an outstanding plant diversity in the tropical Andes of Southern Ecuador. Landscape Online 12:1-35. doi:10.3097/LO.200912

Ronquist F, Huelsenbeck JP (2003) MRBAYES: Bayesian phylogenetic inference under mixed models. Bioinformatics 19:1572-1574. doi:10.1093/bioinformatics/btg180

Ruiz LH, Pavon JA (1794) Florae Peruvianae, et Chilensis Prodromus. Paleariniano, Rome

Saitou N, Nei M (1987) The neighbor-joining method: a new method for reconstructing phylogenetic trees. Molec Biol Evol 4:406-425

Schuiteman A, Chase M (2015) A reappraisal of Maxillaria (Orchidaceae). Phytotaxa 225:1-78. doi:10.11646/phytotaxa.225.1.1

Sosef MSM (1997) Hierarchical models, reticulate evolution and the inevitability of paraphyletic supraspecific taxa. Taxon 46:75-85. doi: $10.2307 / 1224293$

Stegemann S, Keuthe M, Greiner S, Bock R (2012) Horizontal transfer of chloroplast genomes between plant species. Proc Natl Acad Sci USA 109:2434-2438. doi:10.1073/pnas.1114076109

Swofford DL (2000) PAUP*: phylogenetic analysis using parsymony (*and other methods). Version 4.0b2. Sinauer Associates, Sunderland

Szlachetko DL (1995) Systema Orchidalium. Fragm Florist Geobot 3:1-152

Szlachetko DL, Veyret Y, Mytnik-Ejsmont J, Sawicka M, Rutkowski P, Baranow P (2012) Orchids of Frnch Guiana. Koeltz Scientific Books, Königstein

Thiers B (2017) Index Herbariorum: a global directory of public herbaria and associated staff. New York Botanical Garden's Virtual Herbarium, Bronx. Available at: http://sweetgum.nybg. org/ih/

Zhang N, Zeng L, Hongyan S, Hong M (2012) Highly conserved lowcopy nuclear genes as effective markers for phylogenetic analyses in angiosperms. New Phytol 195:923-937. doi:10. 1111/j.1469-8137.2012.04212.x 